\title{
SPECIFICITY OF AUTO-ANTIBODIES IN ACQUIRED HAEMOLYTIC ANAEMIA
}

\author{
BY \\ J. V. DACIE AND MARIE CUTBUSH \\ From the Department of Pathology and the M.R.C. Blood Transfusion Research Unit, \\ Postgraduate Medical School, London
}

(RECEIVED FOR PUBLICATION DECEMBER 8, 1953)

Until recently it has been assumed that the autoantibodies found in acquired haemolytic anaemia are non-specific; that is to say they react with all types of human red cells and are unrelated to any known blood group antibodies. However, Weiner, Battey, Cleghorn, Marson, and Meynell (1953) have described a patient in whom the auto-antibody had the specificity anti-e, the patient's red cells having the genotype CDe/CDe: the same phenomenon had previously been suspected in a patient investigated by Dr. Ruth Sanger (personal communication).

In the course of investigating a severe case of acquired haemolytic anaemia (Case 1), we noted that the patient's serum strongly agglutinated red cells of the genotypes $\mathrm{CDe} / \mathrm{CDe}$ and cde/cde but not those of $\mathrm{cDE} / \mathrm{cDE}$. Further investigation showed that the patient's serum contained anti-C and anti-e, despite the fact that the patient's genotype was $\mathrm{CDe} / \mathrm{cde}$. This observation led to the re-investigation of nine other cases of acquired haemolytic anaemia whose warm auto-antibodies had been considered to be non-specific; the findings are described briefly in the present report.

\section{Materials and Methods}

The red cells from each of the 10 patients in whom acquired haemolytic anaemia had been diagnosed gave a positive direct Coombs test. In each case when the red cells were tested against serial dilutions of a highly potent antiglobulin serum a prozone was observed. As with red cells sensitized by anti-D, the agglutination was readily inhibited by adding small amounts of human gamma-globulin to the antiglobulin serum (Dacie, 1951). The patients' sera were known to contain cold antibodies in very low titre only.

In eight of the 10 cases, the $R h$ genotype of the patients' cells had been determined; the remaining two patients were no longer available. All 10 patients had received blood transfusions during the course of their illness.
The specificities of the antibodies in the patients' sera were investigated, using red cells from normal persons. The sera were tested for their ability to agglutinate trypsinized red cells (at $37^{\circ} \mathrm{C}$.) and to sensitize red cells to an antiglobulin serum (at $37^{\circ}$ C.). When possible, eluates were prepared from the patients' red cells by the method of Kidd (1949), and were then tested for the presence of antibodies. In addition, the sera and the eluates were absorbed with red cells of different genotypes and then tested against a panel of cells.

In these tests, red cells of the $R h$ genotypes $\mathrm{CDe} / \mathrm{CDe}, \mathrm{cDE} / \mathrm{cDE},-\mathrm{D}-/-\mathrm{D}$ - and cde/cde were used; their $F$ f constitution was not known with certainty, except in the case of one $\mathrm{Rh}$-negative sample of the rare genotype cdeF/cdef. The reactions of all these cells with the following antisera had been determined: anti-M, anti-N, anti-S, anti$\mathrm{P}$, anti-Le ${ }^{\mathrm{a}}$, anti-Le ${ }^{\mathrm{b}}$, anti- $\mathrm{Lu}^{\mathrm{a}}$, anti-K, and anti-Fy ${ }^{a}$; in some cases their reactions with anti$\mathrm{Jk}^{\mathrm{a}}$ and anti-Jk ${ }^{\mathrm{b}}$ had also been determined. Cells from donors of group $\mathrm{O}$ were used in the majority of tests. In some cases, where the patient was group $A$, the serum was tested with red cells of group $A$ and of group $O$. The -D-/-D- cells were obtained from the subject described by Race, Sanger, and Selwyn (1951).

\section{Results}

In only one case (Case 1, Ew., already mentioned above) did the patient's serum fail completely to react with cells of the genotypes $\mathrm{cDE} /$ cDE and -D-/-D-. This patient's serum nevertheless agglutinated her own cells and other cells containing the antigens $\mathrm{e}$ or $\mathrm{C}$; it appeared to contain anti-e and anti-C but no non-specific antibody. That the serum did in fact contain anti-e was confirmed by tests with red-cell samples from 22 persons of known genotype, all of whom lacked the antigen $C$; five of them were of the genotype $\mathrm{cDE} / \mathrm{cDE}$. The serum failed to react only with 
those samples which lacked the antigen $e$, as follows :

$$
\text { Reactions with Ew. serum }\left\{\begin{array}{cr}
\text { Red Cells } \\
\mathrm{e}+ & \mathrm{e}- \\
+17 & 0 \\
-0 & 5
\end{array}\right.
$$

The probability of getting such a result by chance is less than 1 in 26,000 .

The anti-e could be removed by repeated absorptions with cde/cde cells. After absorption the serum was tested with red-cell samples from 14 persons, all of whom possessed the antigen e ; eight of these also possessed the antigen $C$. The absorbed serum gave the following reactions:

$$
\text { Reactions with absorbed Ew. serum }\left\{\begin{array}{cc}
\text { Red Cells } \\
\text { C }+ \text { C }- \\
8 & 0 \\
-0 & 6
\end{array}\right.
$$

These results showed that anti-C was present in the serum, since the probability of getting this distribution by chance is 1 in 3,000 .

It was concluded that, despite the fact that this patient's own red cells contained the antigens $\mathrm{C}$ and (genotype $\mathrm{CDe} / \mathrm{cde}$ ), her serum contained the antibodies anti-C and anti-e. The patient was acutely ill and died of her disease a few days after admission to hospital. Unfortunately an eluate was not prepared from her cells.

In all the other nine cases investigated the patients' sera, at $37^{\circ} \mathrm{C}$., reacted to some extent with all the samples of red cells against which they were tested, as well as with the patients' own red cells ; that is to say, the sera apparently contained warm non-specific antibodies. However, it was soon obvious that in some cases the reactions were consistently stronger with red cells of a particular genotype, suggesting that specific antibodies were also present. These specific antibodies were of two kinds: those reacting with antigens not present in the patients" own cells ("immune iso-antibodies") and those reacting with antigens present in the patients' own cells (" auto-antibodies").

It was concluded that the immune iso-antibodies had been formed as a result of previous transfusions. These antibodies could be identified as anti-E in three cases and as anti-c plus anti-E in one case. In Case 8, the anti-E was thought to be an immune iso-antibody, although the patient's $R h$ genotype had not been determined.

The specificity of the auto-antibodies could be investigated most directly by examining an eluate prepared from the patient's own red cells. Eluates were prepared in five cases; they were tested for their ability to agglutinate trypsinized cells and to sensitize cells to an antiglobulin serum both before and after absorption with trypsinized cells and with normal red cells. Some of the findings in three of these cases are shown in Table $I$.

In Case 2, the unabsorbed eluate reacted more strongly with red cells containing the antigen e, and after absorption with $\mathrm{cDE} / \mathrm{cDE}$ cells it reacted exclusively with e-positive cells. It was concluded that the eluate contained anti-e. The eluate appeared also to contain non-specific antibody ; it reacted with e-negative cells and this activity could be removed by absorption with cells of genotype $\mathrm{CDe} / \mathrm{CDe}, \mathrm{cDE} / \mathrm{cDE}$ or cde/cde. However, after one absorption with -D-/-D- cells, the eluate still reacted with $\mathrm{cDE} / \mathrm{cDE}$ cells, although it no longer reacted with -D-/-D- cells (see Table I). Such behaviour was not consistent with that of a single non-specific antibody but suggested the presence of two components in addition to anti-e.

In Cases 4 and 6, the unabsorbed eluates reacted equally well with red cells of all groups and at first appeared to contain wholly non-specific antibodies. In Case 4, after absorption with cells of genotype $\mathrm{CDe} / \mathrm{CDe}, \mathrm{cDE} / \mathrm{cDE}$ or cde/cde, the eluate failed to sensitize cells of any group ; however, as in Case 2 , the antibody which reacted with these cells was not removed comp'etely by absorption with -D-/-D- cells. The antibody present in the eluate of Case 6 behaved similarly after absorption with -D-/-D- cells (see Table I). The antibodies, other than anti-e, detected in the eluates of Cases 2,4 , and 6 , are referred to in the tables as "nonspecific antibody plus an unidentified component." The non-specific antibody reacted with, and was absorbed by, red cells of all the genotypes tested ; the other component reacted with, and was absorbed by, all types of red cell except -D-/-D-. Neither component appeared to be related to a known blood-group antigen.

In view of the strong sensitization of normal cells by some eluates (such as that of Case 2) in which the presence of anti-e was suspected, an attempt was made to demonstrate that these cells were " blocked," i.e., were no longer agglutinated by anti-e. Unfortunately only a very weak salineagglutinating anti-e was available and the results were inconclusive.

The findings in all 10 cases are summarized in Table II. It will be noted that in some cases the antibody, both in the serum and the eluate, acted preferably with trypsinized cells, and in a few cases was detectable only with trypsinized cells. For instance, in the eluate of Case 4 specific autoantibodies were detected using trypsinized cells although none was demonstrable by the indirect 
TABLE I

REACTIONS OF NORMAL RED CELLS WITH ELUATES PREPARED FROM THE RED CELLS OF THREE PATIENTS WITH ACQUIRED HAEMOLYTIC ANAEMIA (RESULTS OF INDIRECT COOMBS TEST)

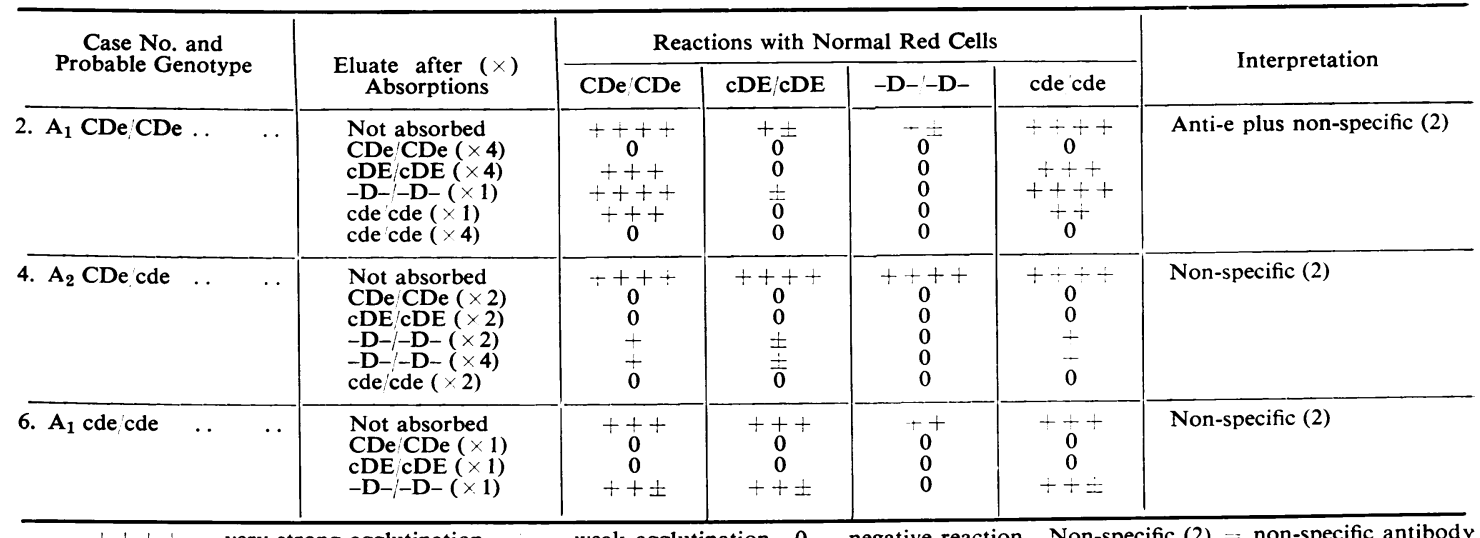
$++++=$ very strong agglutination.
plus an unidentified component.

TABLE II

FINDINGS IN 10 CASES OF ACQUIRED HAEMOLYTIC ANAEMIA

\begin{tabular}{|c|c|c|c|c|}
\hline \multirow{3}{*}{ Case } & \multirow{3}{*}{$\begin{array}{c}\text { Patient's ABO Group } \\
\text { and } \\
\text { Probable Rh Genotype }\end{array}$} & \multicolumn{3}{|c|}{ Apparent Specificity of Antibody Components } \\
\hline & & \multirow{2}{*}{$\begin{array}{l}\text { Immune } \\
\text { Iso-antibodies }\end{array}$} & \multicolumn{2}{|c|}{ Auto-antibodies } \\
\hline & & & Serum & $\begin{array}{l}\text { Eluate from } \\
\text { Patient's Cells }\end{array}$ \\
\hline $\begin{array}{l}\text { 1. Ew. } \\
\text { 2. Fo. } \\
\text { 3. Fi. } \\
\text { 4. Co. } \\
\text { 5. Da. } \\
\text { 6. Ka. } \\
\text { 7. Ho. } \\
\text { 8. Pe.* } \\
\text { 9. Al. } \\
\text { 10. To. }\end{array}$ & $\begin{array}{l}\text { B CDe cde } \\
\mathbf{A}_{1} \mathrm{CDe} / \mathrm{CDe} \\
\mathrm{B} \mathrm{CDe} / \mathrm{cde} \\
\mathbf{A}_{2} \mathrm{CDe} / \mathrm{cde} \\
\mathbf{A}_{1} \mathrm{CDe} \text { cde } \\
\mathbf{A}_{1} \mathrm{cde} / \mathrm{cde} \\
\mathbf{A}_{1} \mathrm{CDe} / \mathrm{cDE} \\
\mathrm{B} \mathbf{R h}+ \\
\mathrm{A} \mathbf{R h}+ \\
\mathrm{O} \mathrm{CDe} / \mathrm{CDe}\end{array}$ & $\begin{array}{c}\text { None } \\
\text { Anti-E } \\
\text { None } \\
\text { Anti-c + anti-E } \\
\text { None }\end{array}$ & $\begin{array}{l}\text { Anti-C }+ \text { anti-e } \\
\text { Anti-e }+ \text { ? non-specific } \\
\text { Anti-e }+ \text { non-specific } \\
\text { Anti-e + non-specific } \\
\text { Anti-e + non-specific } \\
\text { Non-specific }+ \\
,+ \\
,+ \\
, \ddagger\end{array}$ & 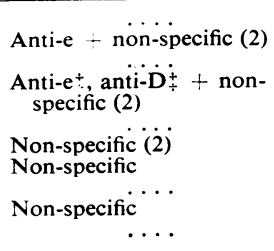 \\
\hline
\end{tabular}

$\ldots \ldots=$ not tested. Non-specific $(2)=$ non-specific antibody plus an unidentified component. $\dagger=$ acted preferably with trypsinized cells $\ddagger=$ reacted with trypsinized cells only. * It was assumed that this patient lacked the $E$ antigen, although the $R h$ genotype was not determined

Coombs test. Anti-e was found in eluates obtained early in this patient's illness: anti-D was found in later samples.

\section{Discussion}

The majority of patients suffering from acquired haemolytic anaemia form antibodies of the "warm" type: i.e., their serum does not contain abnormal amounts of cold antibody and their red cells, when tested with an antiglobulin serum, react as if sensitized with anti-Rh. All 10 cases described here were of this type.

In the five cases in which the patient formed an auto-antibody reacting with specific antigens, the antibody was found to have specificity within the Rh system: anti-e + anti-C (one case) anti-e + anti-D (one case), anti-e (three cases). It is perhaps remarkable that, since anti-D is formed so readily as an immune iso-antibody, only one of the nine D-positive patients formed anti-D as an autoantibody. In contrast, anti-e, which is so seldom found as an immune iso-antibody, was formed by five patients as an auto-antibody.

In most cases auto-antibodies without apparent specificity were also present. In three cases such antibodies were found together with an antibody which was absorbed by all types of cells except -D-/-D- cells. This suggests that the -D-/-Dcells lacked an antigen other than c, C, e and E.

Recently, Wiener, Gordon, and Gallop (1953) have concluded that the warm antibodies formed in patients with acquired haemolytic anaemia are directed "against the nucleus of the $\mathrm{Rh}-\mathrm{Hr}$ substance." Our findings certainly support the idea that in some cases the warm auto-antibodies of acquired haemolytic anaemia may be indistinguishable from immune $\mathrm{Rh}$ antibodies. 


\section{Summary}

An attempt has been made to determine the specificity of the warm auto-antibodies developed by 10 patients with acquired haemolytic anaemia.

In five cases the auto-antibodies were directed against $R h$ antigens (e, $C$ or $D)$. In nine of the 10 cases auto-antibodies of apparently non-specific nature were present.

Four patients also developed anti-E, probably as the result of previous transfusions.

We should like to thank the physicians of the Postgraduate Medical School of London for permission to investigate patients under their care. Other patients have been investigated through the courtesy of Drs.
J. O. M. Edgecombe, E. H. Hempstead, G. B. Hollings, F. Rackow, A. I. Ross, J. Stewart, and G. H. Tovey. We are greatly indebted to Dr. Dorothy M. Parkin and to Dr. J. R. E. Richardson for samples of red cells of rare genotypes, to Dr. E. M. Martland and Dr. J. G. Selwyn for a sample of blood of genotype -D-/-D-, and to Dr. Sheila Worlledge for her help during this investigation.

\section{REFERENCES}

Dacie, J. V. (1951). Lancet, 2, 954.

Kidd, P. (1949). Journal of Clinical Pathology, 2, 103.

Race, R. R., Sanger, R., and Selwyn, J. G. (1951). Brit. J. exp. Path., 32, 124.

Weiner, W., Battey, D. A., Cleghorn, T. E., Marson, F. G. W., and Meynell, M. J. (1953). Brit. med. J., 2, 125.

Wiener, A. S., Gordon, E. B., and Gallop, C. (1953). J. Immunol., $\mathbf{7 1}, 58$. 